Vol. 1, No. 2, 2019

DOI 10.23939/jtbp2019.02.001

Volodymyr Yehorchenkov, Lidiia Koval, Oleh Sergeychuk, Vsevolod Buravchenko

\title{
SIMULATION OF SOLAR ENERGY GAIN THROUGH NATURAL LIGHTING SYSTEMS OF COMPLEX GEOMETRY
}

\author{
Chair of Architectural Structures, \\ Kyiv National University of Construction and Architecture \\ egval@ukr.net
}

(C) Yehorchenkov V., Koval L., Sergeychuk O. and Buravchenko V., 2019

Natural lighting systems are important for the energy efficiency of the buildings.

Thus the size of light openings should be optimized to provide visual comfort and decrease the energy needed to provide comfort in the environment. There exist tools to calculate solar energy gain in the buildings of mass construction with enclosing structures in the shape of horizontal and vertical planes. For structures with curvilinear surfaces systems of equations are compiled, to be solved by numerical methods with significant use of computer time. The article proposes a method of simulation solar energy gain for non-standard enclosing structures for buildings surrounded by existing housing using an apparatus of Balyuba-Naidysh point calculation (BN-calculus). Apparatus of BN-calculus allows forming of a point set optimized to match the shape of a geometrical object. Received point set is used to form elementary solid angles within which energy inflows from direct, scattered and reflected solar radiation into computational points are calculated. The sum of elementary values of energy inflows defines the total value of energy gain of the room.

Key words: solar energy gain; geometrical modelling; BN-calculus; natural lighting systems; point set; solar radiation

\section{Introduction}

The problem of energy saving acquires currently a global pattern since the use of hydrocarbon fuels approaches a critical level and mankind has not yet found a sufficiently cheap and technologically advanced type of renewable energy resources. This worsens the ecological state of the environment and forces climate change. There are certain achievements in solving this problem, but there is still a lot to be done [Mkhitaryan, 1999]. Ukraine has adopted a number of laws and legislative acts including the law of Ukraine "On the energy efficiency of buildings" [Law of Ukraine, 2017], that determine state policy on this issue.

A significant part of the energy saving in housing belongs to natural lighting systems [Martynov, 2013; Sergeychuk, 2001; Sergeychuk, 2004]. On one hand, they form the visual and psychological comfort in the rooms, on the other hand, they significantly influence the energy balance of the building. In winter, windows and lanterns are a weak link in the insulating encasement of the building. In summer they can cause overheating and visual discomfort due to brilliance. Therefore, architects seek to reduce the area of the glazing to a minimum value, which provides comfortable conditions for natural lighting [Natural and artificial lighting, DBN, 2018]. Thus, the area of the glazing should be optimal for creating comfort in the rooms and reducing energy consumption for building maintenance. Tools of simulation of solar energy gain proposed in [Energy performance of buildings, DSTU, 2015; Fanger, 1967] are just approximate and can be used only to calculate solar energy gain in the buildings of mass construction with enclosing structures in the shape of horizontal and vertical planes. If the building has a curvilinear shape or non-standard windows and surfaces, then, in this case, it is necessary to create a system of equations [Tabunshchikov, 2002] and utilize numerical methods, which significantly increase the difficulty of the problem and the computer time required for its solution. Therefore, the authors usually accept the following simplifications: the rooms are encased with by rectangular planes that are parallel or at perpendicular to each other and do not shade each other. 
However, modern architecture often utilizes non-standard plans of buildings, which need to be optimized for energy efficiency too.

\section{Target of this article}

This article is intended for the development of calculus of solar energy gain for non-standard enclosing structures and urban planning environment using the mathematical apparatus of point calculation (BN-calculus) [Naydysh, 1994; Balyuba, 2015; Adonyev, 2017].

\section{Techniques used}

The main element in point calculus is a point, which is described with several parameters. Points calculus offers various ways of organizing a point set, which leads to the creation of elements capable of displaying a geometric scheme for solving the problem posed (Konopatsky, 2008). This scheme can be further used to determine the parameters of the environment.

A distinctive feature of point calculus is the projection of points not onto the projection planes, as in ordinary geometry, but directly onto the coordinate axes. This simplifies the development of the program and reduces the computer time required. The sets of scanning points form an emitting, irradiated or reflecting the physical flux plane or surface without approximation, unlike the existing tools that utilize the numerical method. As a result, the accuracy of calculations increases and the required time decreases.

In BN-calculus, the real geometry of the lighting systems is not replaced by any artificial mesh but is formed as a set of points matching this geometry, however, complex it may be. This allows representing any geometric algorithm in the form of analytical equations that form the basis of the calculation method. Dot calculus allows you to work in the local coordinate system, and get the result in the global system, and vice versa. Moreover, the transition from one to another coordinate system is performed automatically.

As an example, let's consider a non-standard light opening of the curvilinear building in the city of Sopot (Poland) (Fig. 1a). Let's define the necessary accuracy of calculations. We compile point equations for all surfaces in the room that are turned inward, and, according to the accepted accuracy, calculate the coordinates of the points of scan [Yehorchenkov, 2015]. Then we do the same for the surfaces of the light openings.

Obtaining a point set for enclosing structures of the house is shown on the example of a convex quadrilateral curvilinear light opening $A_{1} C_{1} A_{3} C_{4} A_{2} C_{3} A_{4} C_{2}$ (Fig. 1b). The coordinates of the vertices of the corners and arcs, as well as the centre point $R\left(x_{R}, y_{R}, z_{R}\right)$ are set during the design. Point equations of the sides of a quadrilateral are composed in one direction in the form of, for example, parabolas:

$$
\begin{aligned}
& P_{i}=A_{3}(1-t)(1-2 t)+4 C_{1} t(1-t)+A_{1} t(2 t-1) ; \\
& Q_{i}=A_{2}(1-t)(1-2 t)+4 C_{3} t(1-t)+A_{4} t(2 t-1) ; \\
& R_{i}=C_{4}(1-t)(1-2 t)+4 R t(1-t)+C_{2} t(2 t-1),
\end{aligned}
$$

where $P_{i}, R_{i}$ i $Q_{i}$ are the current points of corresponding $\operatorname{arcs} A_{1} C_{1} A_{3}, C_{4} R C_{2}$ i $A_{4} C_{3} A_{2}$.
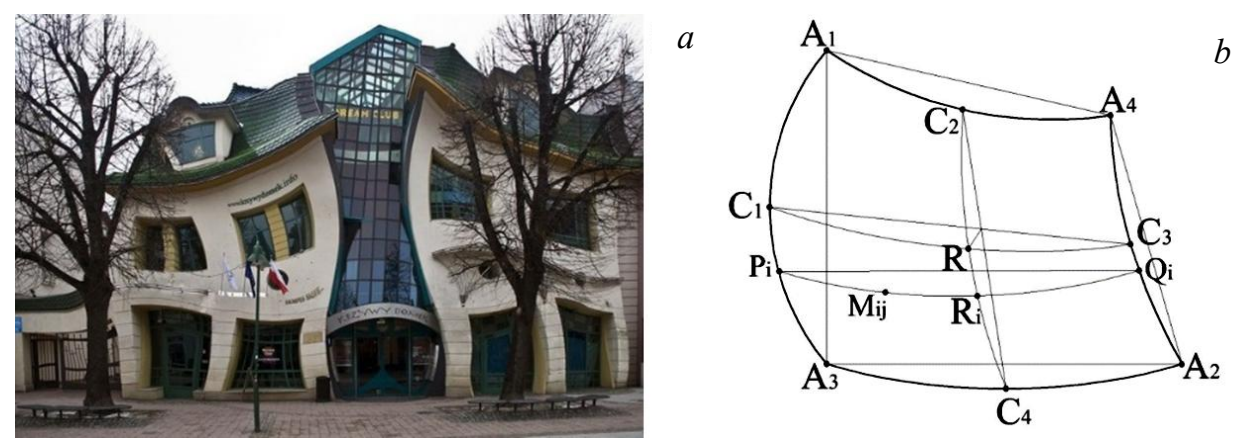

Fig. 1. An example of using quadrangular light apertures with curvilinear sides in the "curved house" in the city of Sopot (Poland) (a), the calculated window layout (b) 
Then a point arc equation is compiled for scanning in the other direction $P_{i} R_{i} Q_{i}$. Here, a form of a parabola is also accepted, although it can be another type of curve:

$$
M_{i j}=P_{i}(1-\tau)(1-2 \tau)+4 R_{i} \tau(1-\tau)+Q_{i} \tau(2 \tau-1),
$$

where $M_{i j}$ is a current point of scan in the boundaries of a flat; $t$ and $\tau$ are parameters that describe the movement of the point $M_{i j}$ in two directions. They vary from 0 till 1 according to the chosen number of points of scan $m$ и $n$, according to the required accuracy of calculations. Software implementation of equations (3) in the form of coordinates is presented at a Fig. 2.

$$
\begin{aligned}
& x_{i j}=x_{P i}(1-\tau)(1-2 \tau)+4 x_{R i} \tau(1-\tau)+x_{Q i} \tau(2 \tau-1) ; \\
& y_{i j}=y_{P i}(1-\tau)(1-2 \tau)+4 y_{R i} \tau(1-\tau)+y_{Q i} \tau(2 \tau-1) ; \\
& z_{i j}=z_{P i}(1-\tau)(1-2 \tau)+4 z_{R i} \tau(1-\tau)+z_{Q i} \tau(2 \tau-1),
\end{aligned}
$$

The proposed method for the simulation of solar energy gain at a given point of the room is as follows. Total solar energy gain over the estimated time period, $Q_{s o l}^{\Sigma}, \mathrm{W} \cdot \mathrm{h}$ in the optical part of the spectrum includes three components:

$$
Q_{s o l}^{\Sigma}=Q_{s o l}^{s t r}+Q_{s o l}^{s c}+Q_{s o l}^{r e f},
$$

where $Q_{s o l}^{s t r}$ is gain from direct solar radiation that reaches the room directly from the Sun, $W \cdot h$; $Q_{s o l}^{s c}$ is gain from solar radiation scattered in the atmosphere, $\mathrm{W} \cdot \mathrm{h} ; Q_{s o l}^{\text {ref }}$ is gain from solar radiation reflected from the ground and ground objects, $\mathrm{W} \cdot \mathrm{h}$.

The first component is determined from the expression:

$$
Q_{s o l}^{s t r}=\left(\sum \Phi_{s o l, \mathrm{ev}}^{s t r}\right) \cdot t
$$

where $\Phi_{s o l, \varepsilon v}^{s t r}$ is monthly average energy flux onto the $\varepsilon v$-th element of the room encasement, which is formed by four (or three) adjacent scanning points, from direct radiation of the solar disk $W ; t$ is the duration of the current month, expressed in hours.

Direct energy flux from the solar disk incoming onto the $\varepsilon v$-th element of encasement at the moment of time $k$ is determined by the formula:

$$
\Phi_{s o l, \varepsilon v, k}^{s t r}=\frac{I_{\mathrm{o}} \cdot p^{M} \cdot \tau_{\mathrm{o}}}{\Delta} \cdot f_{\text {sol }, \mathrm{ev}} \cdot \cos \alpha_{\varepsilon v},
$$

where Io is solar constant, equal to $1366.1, \mathrm{~W} / \mathrm{m}^{2} ; \Delta$ is the distance from the Sun to Earth in astronomical units; $p$ is

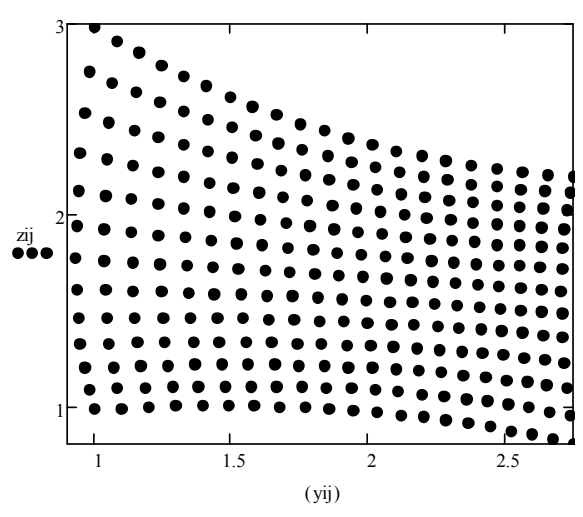

Fig. 2. Formation of a point set for a quadrangular light opening with curvilinear contours in Mathcad environment transparency of the atmosphere, $M$ is air mass of the atmosphere (Bemporad, 1907); $f_{\text {sol }} \varepsilon v$ is the area of the surface element that is insolated, $\mathrm{m}^{2} ; \alpha \varepsilon v$ is angle between the sunbeam and the normal to the surface of $\varepsilon v$-element; $\tau$ o is a coefficient which describes radiation losses during the passage of direct radiation flux through the window filling of the opening.

The second component - the total solar energy gain of the room, incoming with the scattered radiation from the sky over the entire optical spectrum, is determined using the BN-calculus by the formula

$$
Q_{s o l}^{s c}=\left(\sum_{\mathrm{\kappa} \mathrm{l}} \sum_{\varepsilon \mathrm{v}} \Phi_{s o l, \varepsilon v}^{s c}\right) \cdot t
$$

where $\Phi_{s o l, \varepsilon v}^{s c}$ is monthly average energy flux onto the $\varepsilon v$-th element of the room encasement from ij-th elementary part of the sky that is bounded by adjacent scan points, W (Fig. 3); $t$ is the same as in the formula (5). 


$$
\Phi_{s o l, \varepsilon v, k}^{s c}=L_{s o l}^{z} g_{i j} \tau_{w} \sigma_{i j} f_{\varepsilon v},
$$

where $L_{\text {sol }}^{z}$ is energy brightness in the zenith of the sky in the optical spectrum (according to materials of European project Satellight [Satellight, 1996], W· $\cdot \mathrm{sr}^{-1} \cdot \mathrm{m}^{-2} ; g_{i j}$ coefficient of relative energy brightness of the $i j$-th elementary part of the sky in the direction from the center of the elementary area of the irradiated surface to the center of the elementary part of the light-opening; $\tau_{w}$ transmittance of scattered solar radiation by window filling; $f_{\varepsilon v}$ is area of the element of the irradiated surface, $\mathrm{m}^{2} ; \varepsilon$ and $v$ are numbers of elements of the irradiated surface in two directions; $i$ and $j$ are the numbers of elementary parts of the sky visible from a given point through the opening, in two directions; $\sigma_{i j}$ is the value of the projection vector of the elementary solid angle of the $i j$-th element of the sky onto the vector $R$ normal to the element of the irradiated surface (Fig. 3b). This value is determined by the formula of Wiener [Wiener, 1884].

$$
\sigma_{i j}=\frac{1}{2}\left(\alpha_{i j}^{(i+1) j} \cdot \cos \beta_{i j}^{(i+1) j}+\alpha_{(i+1) j}^{(i+1)(j+1)} \cdot \cos \beta_{(i+1) j}^{(i+1)(j+1)}+\alpha_{(i+1)(j+1)}^{i(j+1)} \cdot \cos \beta_{(i+1)(j+1)}^{i(j+1)}+\alpha_{i(j+1)}^{i j} \cdot \cos \beta_{i(j+1)}^{i j}\right) .
$$
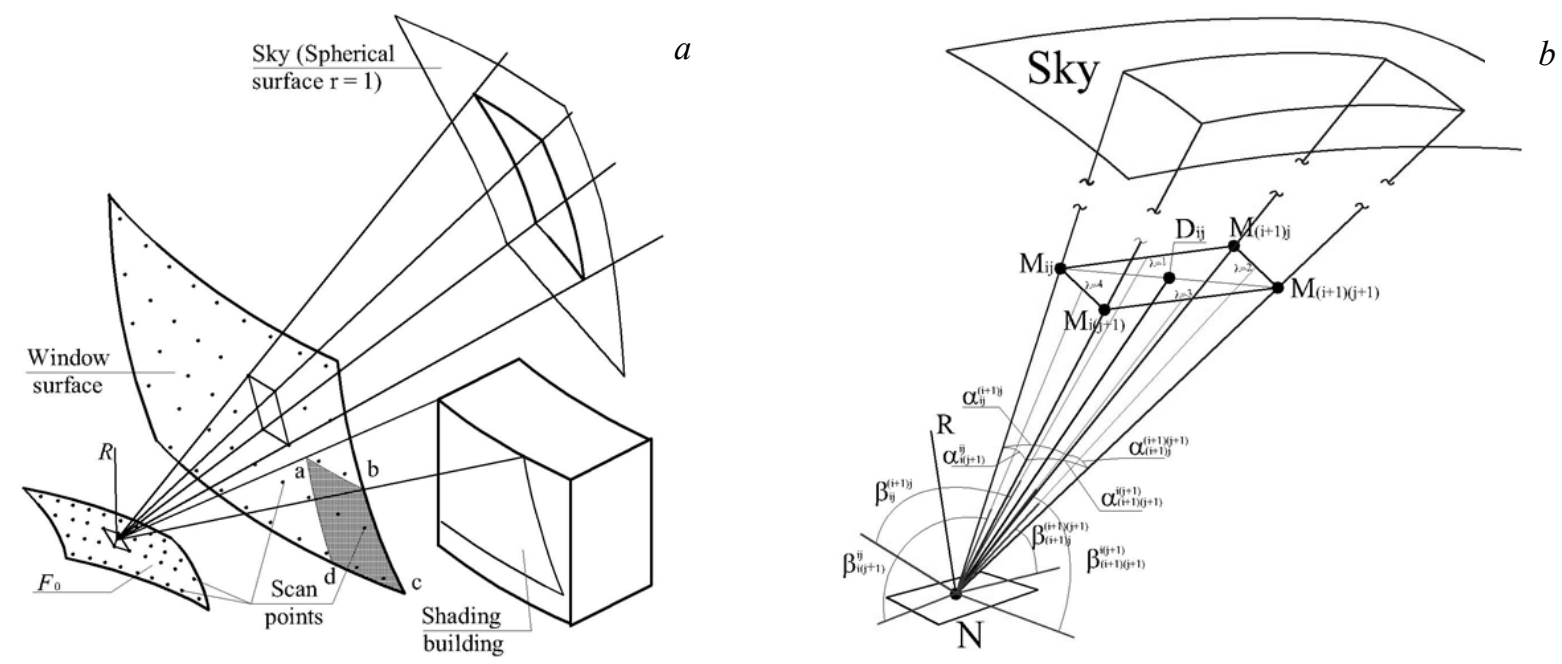

Fig. 3. The layout of the elements involved in the process of solar energy gain: a - the relative position of the window and surfaces; $b$ - the elementary solid angle of irradiance

Solar energy gains incoming into the room through the opening with radiation reflected from the ground and the facades of opposing buildings are calculated by the formula:

$$
Q_{\text {sol }, \mathrm{sv}}^{\text {surf }}=Q_{\text {sol, }, \mathrm{sv}}^{\text {ref }}+Q_{\text {sol }, \mathrm{sv}}^{\text {ref.ld }},
$$

where $Q_{s o l, \mathrm{sv}}^{\text {ref } b \mathrm{~b}}$ is the gain from solar radiation reflected from the facades of surrounding buildings, $\mathrm{W} \cdot \mathrm{h}$.

$$
Q_{s o l, \varepsilon v}^{r e f . b d}=\left(\sum_{\varepsilon v} \sum_{i j} \Phi_{s o l, \kappa \mathrm{k}}^{b d}\right) \cdot t
$$

where $\Phi_{s o l, k, k}^{b d}$ is monthly average energy flux onto the $\varepsilon v$-th element of the room encasement from $\kappa l$-th elementary part of the building's facade, $\mathrm{W} ; t$ is the same as in the formula (5).

$$
\Phi_{s o l, \kappa, k}^{b d}=L_{\kappa \iota} \psi_{\kappa \iota} f_{\varepsilon v} \tau_{w},
$$

where $L_{\kappa 1}$ is energy brightness of the $\kappa \mathrm{l}$-th part of the façade of an opposing building, $\mathrm{W} \cdot \mathrm{sr}^{-1} \cdot \mathrm{m}^{-2} ; \tau_{w}$ and $f_{\varepsilon v}$ the same as in the formula (8).

$L_{\mathrm{\kappa l}, k}$ determined by the energy illumination from the total solar radiation $I_{i n c}^{\mathrm{k}}, \mathrm{W} \cdot \mathrm{m}^{2}$, from the firmament, ground and ground objects incoming onto the $\kappa$-th elementary part of the opposing building's facade using the coefficient of reflection of thermal radiation $\rho_{w}$ of the facade's surface, obeying the law of Lambert. 


$$
L_{\mathrm{\kappa} \mathrm{l}}=\frac{I_{i n c}^{\mathrm{\kappa}} \rho_{w}}{\pi},
$$

where $\psi_{\mathrm{\kappa l}}$ is a coefficient of irradiation of the $\kappa \mathrm{l}$-element of the facade of the opposing building in relation to the $\varepsilon v$-th element of the encasement of the room, sr. Determined in the same way as the projection of the solid angle vector to the normal to the plane by (8). From the town-planning situation, the areas shaded by neighboring buildings are determined, for example, the abcd section (Fig. 3, a). Separate point equations are compiled for them, which form a point set similar to that shown in Fig. 2. Four adjacent scan points are combined into the base of an elementary pyramid for which the irradiation coefficient is determined.

Component of radiation reflected from the ground is determined in a similar way.

$$
Q_{s o l, \varepsilon v}^{r e f . l d}=\left(\sum_{\varepsilon v} \sum_{k l} \Phi_{s o l, k l}^{l d}\right) \cdot t .
$$

The scientific novelty of the proposed calculus lies in the use of a more efficient mathematical apparatus when developing tools for calculating solar energy gain for non-standard solutions of enclosing structures and urban planning environment with a sufficient degree of accuracy. This method differs in that it does not require approximation and compilation of cumbersome equations with the subsequent numerical solution. As a result, the accuracy of calculations increases and the required time is reduced.

The practical value lies in the obtained point equations are, with the help of which a point set of geometric objects is formed. Using the coordinates of scan points, formulas are obtained for determining the values of solar energy gain that can be easily programmed on personal computers.

\section{Conclusions}

1. Studies have shown that the mathematical calculus apparatus is effective for simulation of many physical processes, including the regime of solar energy gain in rooms, which is important from the point of view of creating a comfortable environment and energy efficiency of buildings.

2. A method has been developed for the formation of a regime of solar energy gain in buildings of complex geometry, both from direct sunlight, scattered radiation from the sky and reflected from the ground and ground objects.

\section{References}

Mkhitaryan, N. M. (1999). Energy from unconventional and renewable sources: experience and prospects. Kyiv: Naukova Dumka (in Russian).

Law of Ukraine. On the energy efficiency of buildings. 2118-VIII (2017). Retrieved from https://zakon.rada.gov.ua/laws/show/2118-19 (in Ukrainian).

Martynov, V. L. (2013). The rational orientation of windows in energy-efficient buildings. Energy-Efficiency in Civil Engineering and Architecture (Vol. 4, pp. 185-189). Kyiv: KNUCA (in Ukrainian).

Martynov V. L. (2013). Optimization of the orientation of energy-efficient buildings with compliance with the norms of illumination and insolation. Energy-Efficiency in Civil Engineering and Architecture (Vol. 5, pp. 8489). Kyiv: KNUCA (in Ukrainian).

Sergeychuk, O., Avetikov, A., Lisovets V. (2001). Heat transfer through sloping windows in winter. Vitrina, 10, 16-23 (in Russian).

Sergeychuk, O. V. (2004). Some geometric problems of designing energy-efficient buildings. Collection of Scientific Works. Special Issue: Geometric And Computer Modeling: Energy Saving, Ecology, Design, $148-155$. Kyiv: Vipol (in Russian).

Natural and artificial lighting, DBN V.2.5-28:2018. State Building Codes of Ukraine. (2018). Kyiv: Ukrarkhbudinform (in Ukrainian).

Energy performance of buildings. Method for calculation of energy use for heating, cooling, ventilation, lighting and hot water supply: DSTU B A.2.2-12:2015. National Standard of Ukraine. (2015). Kyiv: Ukrarkhbudinform (in Ukrainian)

Fanger, P. O. (1967). Calculation of thermal comfort: introduction of a basic comfort equation. ASHRAE Transactions 73(2): III.4.1. 
Tabunshchikov, Yu. A. Brodach, M. M. (2002). Mathematical modelling and optimization of thermal efficiency of buildings. Moscow: AVOK-PRESS (in Russian).

Balyuba, I. G. \& Naydysh, V.M. (2015). Point calculus: study guide. Melitopol: MSPU (in Russian).

Adonyev, E. O. (2017). Compositional geometric method. Melitopol: FOP Odnorog T.V. (in Ukrainian).

Naydysh, V. M. \& Vereshchaga, V. M. (1994). Problems of numerical integration. Applied Geometry and Engineering Graphics. (Vol. 57, pp. 21-24). Kyiv: KSTUCA (in Russian).

Konopatsky, Ye. V. (2008). Geometric modelling of algebraic curves and their application in the design of surfaces in a dot calculus of Balyubi-Nidysha. (Doctoral dissertation). Melitopol (in Ukrainian).

Satellight. The European database of daylight and solar radiation. Retrieved from: http://www.satellight.com/core.htm (date: 04.02.2015).

Yehorchenkov, V. \& Konopatsky, Ye. (2015). E. Principles of constructing light field model for a room with curvilinear quadrangular light openings by means of the dot calculation. Light \& Engineering, 23(2), 43-48.

Bemporad, A. (1907). Versuch einer neun empirischen Formel zur Darstellung der Änderung der Intensität der Sonnenstrahlung mit der Zenitdistanz. Met. 3s., Bd. 24, H. 7, 306-313.

Wiener Ch. (1884). Lehrbuch der darstellenden Geometrie, T. 1, Leipzig.

В. О. Єгорченков, Л. М. Коваль, О. В. Сергейчук, В. С. Буравченко Київський національний університет будівництва і архітектури, кафедра архітектурних конструкцій

\title{
МОДЕЛЮВАННЯ СОНЯЧНИХ ТЕПЛОНАДХОДЖЕНЬ ВІД СИСТЕМ ПРИРОДНОГО ОСВІТЛЕННЯ СКЛАДНОЇ ГЕОМЕТРІЇ
}

\author{
(С) Єгорченков В. О., Коваль Л. М., Сергейчук О. В., Буравченко В. С., 2019
}

Важливу роль в енергозбереженні будівель відіграють системи природного освітлення. Тому площа світлових прорізів повинна бути оптимізована, щоб забезпечити світловий комфорт у приміщеннях і зниження енерговитрат на підтримку комфортного теплового режиму. Інженерні методи розрахунку сонячних теплонадходжень застосовуються для будівель масової забудови 3 огороджувальними конструкціями у вигляді горизонтальних і вертикальних площин. Для поверхонь криволінійної форми складають системи рівнянь, які розв'язують числовими методами зі значними затратами комп'ютерного часу. У статті запропоновано метод моделювання сонячних теплонадходжень для нестандартних рішень огороджувальних конструкцій в умовах наявної забудови з використанням апарату точкового числення. Апарат точкового числення дає змогу формувати точкову множину, оптимізовану до заданої форми геометричного об'єкта. Отриману множину використовують для формування елементарних тілесних кутів, у межах яких визначаються теплонадходження в розрахункові точки приміщення від прямої, розсіяної та відбитої сонячної радіації. Сума елементарних величин теплонадходження визначає загальну величину теплонадходжень у приміщенні. Дослідження показали, що математичний апарат точкового числення ефективний для моделювання багатьох фізичних процесів, зокрема режиму сонячних теплонадходжень у приміщення, що важливо для формування комфортного середовища та енергоефективності будівель. У результаті розроблено методику формування режиму сонячних теплонадходжень у будівлі складної геометрії як від прямих сонячних променів та розсіяного випромінювання небозводу, так і від променевих потоків, відбитих від поверхонь землі та сусідніх об’єктів. Практичне значення проведеного дослідження полягає у тому, що отримано точкові рівняння, за допомогою яких формують точкову множину геометричних об’єктів. Використовуючи координати точок сканування, одержали формули для визначення величин сонячних теплонадходжень, які легко програмувати на персональних комп'ютерах.

Ключові слова: сонячні теплонадходження; геометричне моделювання; точкове числення; системи природного освітлення; точкова множина; сонячна радіація. 